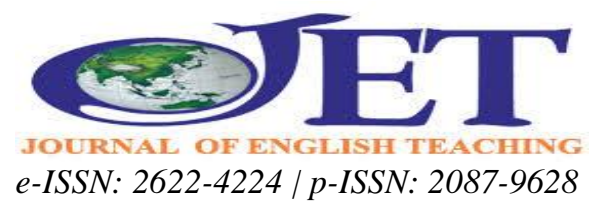

\title{
Using Fiction to Promote Students' Critical Thinking
}

\author{
Parlindungan Pardede \\ parlpard2010@gmail.com \\ Universitas Kristen Indonesia
}

DOI: http://dx.doi.org/10.33541/jet.v5i3.1309

\begin{abstract}
The importance of Critical Thinking (CT) to support every individual's success in academic, personal and social life has long been acknowledged. The accelerating advancement of technology makes the need for CT more crucial. However, due to various factors, CT development through the educational process has not been satisfactory. This article reviews current ideas and studies on the nature of CT, the nature of fiction and their role in developing CT. To get ideas about how to implement using fiction to promote CT, the article ends with the practical description of a step by step of using fiction to promote CT through an instructional model.
\end{abstract}

Keywords: critical thinking, fictions, EFL

\section{INTRODUCTION}

The notions of critical thinking were acknowledged about 2,500 years ago when Socrates introduced the need for promoting human reasoning skills quality by developing the Socratic Method, the process of questioning which constitutes the early criteria of what is known today as Critical Thinking (CT). CT was in vacuum for 20 centuries until Descartes revived and implemented it in the 17th century (Rfaner, 2006). However, it begins to be a prominent component in educational programs by the mid of the 20th century after Dewey (1934) contended that the fundamental purpose of the education system should be learning to think which he referred to as "reflective thinking" and an "active, persistent, and careful consideration of a belief or supposed form of knowledge in the light of grounds which support it" (p. 9).

Prompted by Dewey's ideas, the high importance of CT for one's academic success and social life keeps on being accentuated in western education (Facione, 2015; Moon, 2008). The need for CT was later strengthened by the accelerating advancement of technology which keeps on overloading people with information. Ease of accessing a wealth of information requires people to think critically so that they can discriminate factual from fake information; see logical connections between ideas; be open-mindedly view things from diverse perspectives; identify, construct and evaluate problems and get relevant information to solve them. The World Economic Forum even suggested that in the present economy of constant change and disruption, CT is a skill vital to surviving 
(Gray, 2016). The vital of CT has recently become 'a buzz word' among educators in the whole world.

Unfortunately, CT development among students is still unsatisfactory. Hirose (1992, p. 1), reported that many students today "lack the basic skills to function effectively when they enter the workforce. A common complaint is that entry-level employees lack the reasoning and critical thinking abilities needed to process and refine information". This is clarified by Belkin's (2017) report that large groups of seniors at about half of 200 U.S. colleges scored only at basic or below basic levels, and even at "high-profile colleges" over a third of seniors scored "below-basic skills." In line with this, Berr's (2016) survey of over 76,000 managers and executives revealed that $60 \%$ of new college graduates lack critical thinking skills.

The unsatisfactory development of CT was also found in Asian countries. Rashid and Hashim (2008) indicated that the graduates of Malaysian education system could not meet employers' expectations due to a lack of CT and poor communication skills. In Indonesian context, CT development has not been seriously supported in primary and secondary education. Sadli (2002) stated that education in Indonesia does not promote CT. Rujivanarom (2016) reported that the CT skills of Thai students are very limited. A study evaluating the logical thinking and analytical skills of 6,235 students in ten Thai provinces revealed the average final score was just $36.5 \%$, and only $2.09 \%$ of participants passed the exam.

Tung and Chang (2009) listed three major causes of the problem in the Asian context. First, in their prior learning, students mainly went through reproductionoriented learning activities. They were rarely had the opportunities to question, explain, or evaluate the "knowledge" instructed in the classroom. Second, primary and secondary school teachers received little guidance or support regarding critical thinking instruction. Their opportunity to integrate critical thinking into curricula is also deprived by their teaching load and time constraint. Third, students are more accustomed to a collectivist society, so that they lack individual voice which is necessary for critical thinking. These factors make CT development seems to be more challenging for Asian EFL learners than their counterparts coming from other ethnicities. These points are confirmed by various current studies. Ahn (as cited in Oh, 2017) stated that since secondary education in Korea heavily focuses on rote memorization, most Korean students do not have much experience in critical thinking. Japanese learners are depicted as group-oriented, harmony-seeking, hierarchical, and non-critical thinkers (Atkinson, 1997; Fox, 1994). Taiwanese students in U.S. high school classrooms are depicted as to hold the belief that "being quiet is good" for the students in Taiwan are supposed to be quiet in the classroom (Harklau, 1994).

A number of language learning pundits (Davidson, 1998; Kabilan, 2000; Tang, 2016) have highlighted students' crucial need of CT for their success in learning, workplaces and social life and proposed the integration of CT development into English language curriculum. Kabilan (2000) accentuated that the ability to know the meaning and use of English is not enough. Proficient ESL/EFL learners should be able to display CT through the language. Moreover, CT tends to expand students' learning experience and drives language learning more significant and meaningful. This article reviews current ideas and studies on the nature of CR and fiction and the promotion of CT in EFL classrooms through the use of English fiction. To get ideas about how to implement using fiction to promote $\mathrm{CT}$, the article ends with the practical description of a step by step of using fiction to promote CT through an instructional model. 


\section{DISCUSSION}

\section{The Nature of CT}

CT is a complex mental process. It is a diverse and multidimensional cognitive ability employed to clarify and evaluate the activities and actions conducted by someone (Kong, 2007). Due to its complexity, although considerable attempts to define it have made, a single definition accepted by all has not been formulated. Up to now, different pundits defined it differently (Evers, 2007; Lun et al., 2010) because it is "difficult to define satisfactorily and hard to measure" (Black, 2007, p.4).

However, the majority of ideas attempting to clarify CT offers interpretations that are not very different from another (Pardede, 2015). Halpren (1993) pointed out that the existing definitions share overlapping similarities. Different they may be, the available definitions all characterize CT as a mental process, strategies, or representations with slightly different emphases. Some of them define regard CT as a process of evaluating, some viewed it as a process of thinking, and some others regard it as a means to an end. Halpern (2010), for instance, defined CT as the use of cognitive strategies to improve the expected ideas. Thus, CT covers the skills employed in conclusion drawing, decision making, problem-solving, and the like. According to Ennis (1993), CT is the reasonable reflective thinking focusing on deciding what to believe or do, which comprises thirteen CT dispositions and a set of CT abilities (skills).

The consensus definition of CT derived by Facione (1990) from a panel of 46 CT experts is probably the most comprehensive for it covers the cognitive and dispositional dimensions of CT. The definition views CT as "purposeful, self-regulatory judgment which results in interpretation, analysis, evaluation, and inference, as well as explanation of the evidential, conceptual, methodological, criteriological, or contextual considerations upon which that judgment is based" (Facione, 1990, p. 2). The definition adds personal traits of an ideal critical thinker to its construction of CT, i.e. openmindedness, inquisitiveness, fair-mindedness, flexibility, trust in reason, honesty in facing personal bias, prudence in making judgment, and clarity about issues. This definition is supported by Jones et al. (1995) who described CT as interpretation, analysis, evaluation, inference, presenting, arguments, reflection, and dispositions; and by Paul and Elder (2007) who described that a critical thinker is someone capable of formulating relevant questions, accumulates appropriate information and evaluates it for drawing sound conclusions. At the same time, he is also willing to accept different systems of thought and share them with others to find a common solution. Paul and Elder (2007) accentuated that critical thinking is a "four-self-incorporating concept" as it is "self-directed, self-disciplined, self-monitored and self-correcting thinking." (p. 4).

One of the major breakthroughs resulted from the interest in developing CT as an integral part of education is the increasing publication on CT taxonomies and dispositions, among which the works of Bloom (1956), Ennis (1987) and Facione (1990) are the most influential. Bloom (1956) presented the skills of CT in a hierarchical order. Since his taxonomy differentiates the lower order thinking skills: (application, comprehension, and knowledge) from the higher-order thinking skills (evaluation, synthesis, and analysis), to integrate these skills in the curriculum and evaluate them becomes fairly easy. The taxonomy of Ennis (1987) identifies a group of abilities that a critical thinker should possess as well as several dispositions that will encourage him/her to use these abilities. Facione (1990) acknowledged six critical thinking skills (analysis, interpretation, evaluation, inference, explanation, and self- 
regulation) and two sets of dispositions: approaches to life in general and approaches to specific issues and questions.

\section{Developing CT in EFL Classroom}

Synthesizing the ideas above, in the context of promoting CT in EFL classrooms, CT can be viewed as the ability of students to passionately and responsibly take apply and control of their thinking skills (question, analyze, criticize, reflect, and synthesize), develop proper principles and standards to evaluate their thinking, and willingly judge, accept or reject new ideas, concepts, and viewpoints. To develop CT in EFL classrooms, students should be encouraged to apply and evaluate their thinking skills and nurture honesty, open-mindedness, inquisitiveness, flexibility, and trust in reason in themselves. To make it happen, teachers should teach in that way the students learn.

Shirkhani and Fahim (2011) listed three notable reasons for the significance of promoting CT into EFL classrooms. First, CT enables students to take charge of their thinking. Employing this ability, they can monitor and evaluate their ways of learning more successfully. Second, CT expands students' learning experience and makes the language more meaningful for them. Third, CT significantly and positively correlates with the students' achievements (Fong et al., 2017). Different studies have confirmed the role of critical thinking in improving students' language skills. Rosyati \& Rosna's (2008) study involving Malaysia undergraduate students revealed the participants' English proficiency is positively related to their CT ability. Malmir and Shoorcheh (2012) reported that CT training significantly affected Iranian EFL learners' speaking skills. The study also showed that CT strategies assisted the students to become active participants who listened carefully to other students' lectures, judged those utterances, and decided properly what to say to respond to others during the interaction process. Kamali and Fahim (2011) reported that levels of CT significantly impacted students' reading ability of texts containing unfamiliar vocabulary.

To facilitate CT development in EFL classrooms, every learning activity can and must be integrated with CT development. To illustrate, while reading a passage, the students should not only getting information from it. They should be encouraged to employ their critical skills to understand, question, and evaluate the text so that they can draw a relevant conclusion from it. They should also passionately discuss their understanding one to another for the sake of getting a common ground. To take another illustration, in a class focusing on listening and speaking, students should not be taught to memorize and drill certain expressions. On the other hand, to involve their CT skills, they can be assigned to watch a speech video and analyze the speaker's pronunciation, word, and grammar and share the results in small workgroups. Finishing it, the students are asked to evaluate the speaker's main ideas and supporting details (facts or fabricated data), presentation style, and arguments presented in terms of weaknesses and strengths. Based on this evaluation, the students (individually or in a group) are asked to make a presentation. In short, in EFL learning, students should not only encouraged to discuss and negotiate words, grammar, dialogues, and discourse meaning but are also facilitated to analyze, assess, question, synthesize, reflect, and be skeptical of topics, data and evidence brought into their classroom (Bedir, 2013).

\section{Use of Literature in English Classrooms}

Literary works (poetry, drama, and fiction) have long been used in ESL and EFL classrooms. Many writers and researchers (Collie \& Slater, 1991; Erkaya, 2005; Kaplan, 
2000; McKay, 1987; Murdoch, 2002; Pardede, 2011; Savvidou, 2004) advocate the use of literature in ESL and EFL classrooms due to many reasons. Some of the most important reasons are: literature provides authentic materials, offers meaningful input, improves linguistic knowledge, increases language awareness, enhances communicative competence, develops interpretive skills, promotes cultural understanding, facilitates critical thinking and creativity, and stimulates social development.

\section{Fiction}

Among the three literary genres, fiction is regarded as the most suitable to use in EFL classrooms. In a poem, thoughts and emotions are communicated in a condensed language without spoiling meter and rhyme. To achieve these, poets exploit linguistic convention by producing deviated language (in terms of lexical, semantic, phonological, morphological, and syntactical domain). To attain the goal of communicating an idea and feeling briefly but beautifully, poets also employ figurative languages which enable them to elicit emotion, help readers form mental images, communicate in a more meaningful, vivid, and expressive way, and draw readers into the poem. The deviated and figurative language requires extra thinking and time to grasp the meaning so that students may get bored and discouraged. Drama is a literary genre written to be transformed into actions, dialogues or sights (Angelianawaty, 2019). To use drama in the EFL classroom, the students must first deal with the language structures and items of the work through reading and analysis. After that, they should prepare and plan how to act the workout. Wessels (1987) affirmed: "... drama requires meticulous planning and structuring." Thus, although using drama "allows the teacher to present the target language in an active, communicative and contextualized way" (Mattevi, 2005) so that it is very potential to teach the four language skills, pronunciation and gesture, many teachers find it difficult to use due to the preparation complexity. The use of drama could also be problematic in public schools with overcrowded classes, overloaded syllabus and limited time. Pardede (2011) asserted that to act out a play in crowded classes within limited course hours is difficult.

Fiction refers to invented stories, or stories constructed based on imagination, which includes novels, short stories, novellas, romances, fables, and other narrative works in prose (Baldick, 2001, p.96). Different from poetry which is typically written in stanzas and drama which is written to be performed on a stage, fiction is written in prose. Derived from Latin word "fictus" which means "to form," or "fictiō" which means "the act of making, fashioning, or molding," the term fiction denotes that this literary work uses prose written words to contrive something (the subject matter) which represents human life. The subject matters of fiction may vary. However, they are all related to human experience or conduct employed to interpret life, entertain, educate, inspire, or to express the spirit of its age. It could be based on realities or merely a fantasy. It can be used to explore inner feelings and thoughts, superior but forgotten paradigm, or conflicting values or ideas. It may be placed in a setting taken from the familiar daily life patterns or in an unfamiliar and inventive time or place. Although the subject matter is taken from realities, it is not the real actualities for the author has selected, altered, and rearranged everything to achieve focus and to make clear his vision of life clear.

Although the subject matters of fiction are all related to human life, they are all a creation of the author. The characters, events, settings, and other elements that construct fiction are the creation of the author. They are not reality. A fiction may include 
characters or events that look like individuals or historical events in the actual world. However, they are not identic. The characters and events are the creation of the author. Encyclopaedia Britannica (2019) accentuated that fiction is "created from the imagination, not presented as fact, though it may be based on a true story or situation."

Among the many types of fiction, novels and short story are the modern and living forms of narrative works (Taylor (1999) and both are the most popular literary work since are the most written and read. A novel is "normally a prose work of quite some length and complexity which attempts to reflect and express something of the equality or value of human experience or conduct" Taylor (1991, p. 46). In the same vein, Hawthorn (2001) stated that a novel is a "fiction prose narrative or tale of considerable length in which character and action are representative of real life" (p. 5). Therefore, a novel conveys a connected sequence of events (story) involving a group of people in a particular place and time to present, elaborate, or reflect various real-life problems (as the subject matter).

Although a short story also tells a story, it typically focuses on a single event involving only a few characters. A short story is essentially short, usually 3,500-7,500 words in length. Different from a novel which involves some major characters, conflicts, sub-plots, complications, viewpoint, and settings so that it needs to be read over days, a short story omits a complex plot, discloses the character in action, and limits the setting. Poe (as cited in Abrams, 1970, p. 158) defined the short story as "a narrative that can be read at one sitting of from one- half hour to two hours, and that is limited to a certain unique or single effect, to which very detail is subordinate."

Based on their literature review, Siaj and Farrah (2018) listed three benefits of using novels in EFL classrooms. First, novels are motivating and enhancing learning materials. Most students enjoy reading novels, so they find novels interesting to use as learning materials. Also, since novels deal with events related to life, it enhances students' motivation to read them (Tsai, 2012). Second, novels are believed to enrich the cultural knowledge among students (Alkire, 2010; Lazar, 1990; Tsai, 2012). Alkire (2010) found that novels enable students to understand other peoples' cultures, including how people about whom the novel is written think, behave, and believe. Third, the use of novels, just like other literary genres) develops students' level of language proficiency. Tsai (2012) found that while reading novels, students improve the four language skills; reading, writing, speaking and listening. Fourth, using novels enhances students' ability to interpret and understand the target language. The study of Pinar and Jover (2012) showed novels facilitate students to infer meaning and explain because they have more than one level of meaning.

Despite these advantages, students may face two challenges while reading novels. First, novels may include a large number of unfamiliar words. To overcome this, the teacher can help by providing a glossary for the students or encouraging the students to guess words meaning using the context and infer the general idea, instead of focusing on details. Second, some novels can be very long. Lazar (1990) suggested that teachers should suit the length of the novel to be read with the students' level of proficiency. The teacher can also ask different students to summarize different chapters so that class time can be managed more effectively.

\section{Developing CT through Fictions}

Using novels to promote CT is supported by two underlying reasons. First, like other literary works, a novel is allegorical. It has a literal meaning and implied meaning 
which is beyond the surface. To get the appropriate meaning, the reader should reflect, infer, analyze, and synthesize the presented information. By doing these, the reader has practiced CT skills. Tung \& Chang $(2009$, p. 291) accentuated that literature reading is a complex process requiring the readers to recall, retrieve and reflect on their prior experiences or memories to construct meanings of the text. To do so, they should exhibit various capacities, namely distinguishing facts from opinions; comprehending the literal or implied meanings and the narrator's tone; identifying details related to the issues discussed; searching for the causal relationship or the connections between the events or actions; inferencing the relationship of the details perceived; considering the multiple points of views; making ethical reasoning and fair-grounded judgments; and above all, applying what they have learned from this process to other fields or the real life.

Secondly, as previously described, novels are closely related to life; they are even about life. Although the subject matter is about life, a novel presents it uniquely. The characters may look like people in reality. The actions can take place as if they belong to daily life. However, they are different from the people and the actions in actual life. These features make novels can be perceived as a "simulation of society" which provides the students an opportunity to explore from other perspectives so that they improve their understanding of others (Oatley, 2016). The nature of novels that they are close to life also facilitates students to promote the ability to make a decision, which is one of the major features of CT. By studying novels containing matters directly related to daily life, the students can get schemata about particular matters, store them in their minds, and use them later as a reference in taking up action.

Riecken and Miller (1990) supported these ideas by stating that students will evaluate evidence, draw conclusions, make inferences, and develop a line of thinking if they approach fiction through a problem-solving perspective. Lazere (1987) accentuated that "literature...is the single academic discipline that can come closest to encompassing the full range of mental traits currently considered to comprise critical thinking" (p. 3).

\section{Selecting Fictions to Use}

One of the crucial factors to consider in using fictions to promote CT is selecting the work. Mckay (1982) highlighted that selecting suitable literature is "the key to success in using literature in the ESL". The most important criteria of selecting the literary works to use are: student's language proficiency, personal involvement, length (it suits the time available), cultural competence, intellectual merit (issues and ideas explored in works should be relevant, interesting and challenging to students), literary merit (the work is really worthy of academic study), and contemporary (it uses modern English). To meet the length and complexity criteria, we are fortunate because fiction includes novels and short stories. Since novels are generally longer and more complex, they could be employed in advanced and upper intermediate classes. Short stories, due to their relative simplicity and shortness, are appropriate in primary and intermediate levels.

\section{Instructional Models for Promoting CT in EFL Classrooms}

By combining the conceptual frameworks of how people think critically and creatively and teaching experiences, various researchers (Bobkina \& Stefanova, 2016; Savvidou, 2004; Sousa, 2004; WSSU, 2013) have developed their teaching models for developing 
CT in the English classrooms. Bobkina and Stefanova (2016) built the following model by covering the New London Group's four curricular components for addressing the full range of literacies (p. 68). The model consists of four stages: (1) situated practice, (2) overt instruction, (3) critical framing, and (4) transformed practice. This model is essentially generic. So, it could be easily adapted to suit any classroom environment and meet the students' needs.

It should be underlined that the objective of including CT in the teaching-learning process is not to teach about CT but to let students employ the thinking skills into the learning process. In short, the aim is to facilitate students to infuse their CT while studying. To see how the model works, in the following section it is described in the scenario of studying Animal Farm, a novel by Orwell (1944).

\section{Synopsis of Animal Farm}

Animal Farm is a fable which is told by the narrator through the third-person omniscient (eye of god) point of view. The story takes place on Manor Farm located in England. It starts at one evening when, after Mr. Jones, the farm owner goes to sleep, Old Major, the oldest pig on the farm, calls all animals for an underground meeting in the barn. He tells the other animal that they live in poverty and misery because human beings enslaved them. He persuades human are their enemy. He dreams that the animals will live prosperously if they get rid of humans. So he asks them to revolt against humans. Before closing his speech, Old Major teaches them a song titled Animals of England. The song makes the animal exited and all of them groan while singing it together. The noise wakes Mr. Jones up and he takes his rifle and shoots to the darkness. It silences the whole farm.

When Old Major dies, led by two pigs, Napoleon and Snowball, the animals decide to fulfill his dream. They establish a new government in which animals have rights. They also adopt "The Seven Commandments", the ultimate principles of the farm, in which "All animals are equal" is the most important.

One night, being very hungry because Mr. Jones' men forget to feed them, the animals get angry, they defeat Mr. Jones and run him off the farm. The animals rename the property Animal Farm and run it by themselves. They start learning to read and write and educate all the young using the commandments. Devoting themselves to realize Major's dream most of them work as hard as possible. Meanwhile, a struggle for power begins between Napoleon and Snowball. Being very inventive, Snowball designs and suggests to build a windmill. When it has run, he says, they will work only three days a week. To avoid Snowball's popularity to increase, Napoleon opposes building the windmill and expels Snowball away by setting his dogs against him. After that, Napoleon takes control alone and orders to build the windmill. They work the point of collapsing to build it, but they are always convinced everything is for their future. Boxer, the cart-horse, dedicates his huge strength to build the windmill for the farm's prosperity and adopts the affirmation "I will work harder" as a personal maxim.

As an absolute leader, Napoleon changes the rules over time. He replaces the previous meeting of all animals to a committee of pigs who will run the farm and makes the pigs living luxuriously in Jones' house. Even Boxer is sold and gets killed when he retires. When other animals object to something, Squealer, Napoleon's spokesman, convinces them that Napoleon is always right. When something goes wrong, Squealer uses the expelled Snowball as a scapegoat. 
Things get worse on the farm and the animals work as a slave. The Seven Commandments have now been amended. The one previously runs "All animals are equal" has been added with "but some are more equal than others." The pigs now behave like humans and start to deal with other neighboring farmers. One evening, other farmers visit the farm and the pigs welcome them in Jones' house. As the animals secretly gaze from outside the window, they cannot differentiate the pigs from the humans.

\section{Studying Animal Farm Using Bobkina and Stefanova's Model}

1. The Situated Practice Stage is intended to activate students' schemata on Animal Farm. During this stage, students are let to recall relevant experiences and information they have got. The teacher can initiate activities in this stage by asking the following questions and the students should share their answers one to another.

1. Have you ever read a fable? What is it about? What ideas do you learn from it?

2. Can you describe two or three hoaxes?

3. Why do you think some people can easily believe in hoaxes?

4. Have you ever read the history of despotic systems of government?

5 . Have you ever watched a movie about a revolution?

$6 . . .$. and so on.

Other activities in this stage can include letter writing or searching and sharing short articles relevant to the issues in Animal Farm and share ideas about them.

2. The Overt Instruction Stage is directed for two goals. The first is to achieve a general comprehension of the novel. Students are asked to read the novel quickly. To check their understanding, the teacher can lead a discussion of some key ideas of the novel or administer a general comprehension test. Since the novel has been adapted in movies, letting the students watch one of them might increase their motivation.

The second goal is to achieve deep comprehension by assigning the students to apply the close reading to understand the novel's inner logic. Through the close reading, for instance, students should be able to determine why Snowball adopts the puppies and raise them secretly. They should also be able to interpret why Orwell makes the pigs the most talented or to conclude why at the end of the novel the animals cannot differentiate the pigs from the human. To visualize the close reading, students can be asked to create knowledge maps or revising and editing improper drafts. While doing the close reading, students are encouraged to make notes and later compare them to their peers' ideas. This enables them to understand other students' perspectives.

3. The Critical Framing Stage focuses on developing students' conscious attention to relationships between linguistic forms and social-cultural contexts. For instance, they should be able to explain what the "sugar candy mountain" represents in the novel, and why the character who spreads it named Moses? To get a more accurate conclusion about the issues, characters, and events in the novel, students are encouraged to question and analyze the text and explore the writer's attitude, intention, and viewpoint through the analysis of the lexical and 
structural choices he uses. If such studying a novel for developing critical reading is new for the students, conducting a teacher-led question might be helpful to complete this stage.

4. The Transformed Practice Stage deals with students' production of writing relevant to the novel. Bobkina and Stefanova (2016) suggested that the activities in this stage can consist of paraphrasing the original texts into another mode (e.g, rewriting the lyric of Animals of England into one or more paragraphs). Other recommended activities include writing relevant essays to the novel, inventing story continuations, translation, characterization, and so on.

\section{CONCLUSION}

Based on the discussion above, it can be concluded that using fictions to promote CT in the EFL classroom context can be very effective, interesting, and advantageous. It is effective because the nature of fiction provides many opportunities for the reader to respond, question, and analyze critically. Using fiction as the media of CT development is interesting because this literary genre is close to the students' life. It is advantageous due to two notable points. First, since the students actively employ their CT skills and study individually and in a group in turn during the learning process, they not only develop their CT but also master the novel, develop their English proficiency. Second, since the conclusions they get are critically drawn from literary works, they can be applied in the students' daily life.

\section{References}

Abrams, M.H. (1999). A Glossary of Literary Terms. 7th Ed. Massachusetts: Heinle \& Heinle, Thompson Learning Inc.

Angelianawati, L. (2019). Using Drama in EFL Classroom. Journal of English Teaching, 5(2), 125-134. DOI: http://dx.doi.org/10.33541/jet.v5i2.1066

Atkinson, D. (1997). A critical approach to critical thinking in TESOL. TESOL Quarterly, 31, 71-94.

Baldick, C. (2001). The Concise Oxford Dictionary of Literary Terms. Oxford: Oxford University Press

Belkin, D (2017). Exclusive Test Data: Many Colleges Fail to Improve CriticalThinking Skills. Retrieved June 2018 from https://www.wsj.com/articles /exclusive-test-data-many-colleges-fail-to-improve-critical-thinking-skills1496686662

Bedir, H. (2013). Reading and Critical Thinking Skills in ELT Classes of Turkish Students. World Applied Sciences Journal, 21(10), 1436-1439.

Berr, J. (2016). Employers: New college grads aren't ready for workplace. Retrieved June 2018 from https://www.cbsnews.com/news/employers-new-college-gradsarent-ready-for-workplace/

Black, B. (2007). Critical Thinking - a tangible construct? Research Matters: A Cambridge assessment publication, 3, 2-4.

Bloom, B. S. (1956). Taxonomy of educational objectives. Vol. 1: Cognitive domain (pp.20-24). New York: McKay 
Bobkina, J. and Stefanova, S. (2016). Literature and critical literacy pedagogy in the EFL classroom: Towards a model of teaching critical thinking skills. SSLLT, 6(4), 677-696. DOI: 10.14746/ssllt.2016.6.4.6

Bretz, M. L. (1990). Reaction: Literature and communicative competence: A springboard for the development of critical thinking and aesthetic appreciation. Foreign Language Annals, 23(4), 335-338.

Chi-An, T. \& Shu-Ying, C., (2009). Developing Critical Thinking through Literature Reading. Feng China Journal of Humanities and Social Science, No. 19, 283-317.

Collie, J. \& Slater, S. (1991). Literature in the language classroom. (5th ed.). Glasgow: Cambridge University Press.

Davidson, B. (1998). A case for critical thinking in the English language classroom. TESOL Quarterly, 32, 119-123

Dewey, J. (1934). Art as experience. New York: Minton, Balch, and Co.

Ennis, R. H. (1987). A taxonomy of critical thinking dispositions and abilities. In J. Baron \& R. Sternberg (Eds.), Teaching thinking skills: Theory and practice (pp.926). New York: W.H. Freeman.

Encyclopaedia Britannica. (2019). Fiction. Retrieved May 2019 from https://www.britannica.com/art/fiction-literature

Erkaya, O. R. (2005): Benefits of Using Short Stories in the EFL Context. Asian EFL Journal, Vol. 8, 1-13.

Evers, A. (2007). Does discipline matter? Pedagogical approaches to critical thinking in English for academic purposes (EAP) and economics. Unpublished master's thesis, Carleton University, Ottawa, Ontario, Canada.

Facione P A (2015). Critical Thinking: What It Is and Why It Counts. Insight assessment https://doi.org/ISBN 13: 978-1-891557-07-1.

Facione, P. A. (1990). Critical thinking: A statement of expert consensus for purposes of educational assessment and instruction. Millbrae, CA: The California Academic Press.

Fong, C. J., Kim, Y., Davis, C. W., Hoang, T.,\& Kim, Y. W. (2017). A meta-analysis on critical thinking and community college student achievement. Thinking Skills and Creativity, 26, 71-83.

Fox, H. (1994). Listening to the world: Cultural issues in academic writing. Urbana, Illinois: National Council of Teachers of English.

Gray, A. (2016). The 10 Skills You Need to Thrive in the Fourth Industrial Revolution. Retrieved May 2019 from https://www.weforum.org/agenda/2016/01/the-10skills-you-need-to-thrive-in-the-fourth-industrial-revolution/

Halpern, D. F. (2010). Creativity in college classrooms. In R. A. Beghetto \& J. C. Kaufman (Eds.), Nurturing creativity in the classroom (pp. 380-393). New York, NY: Cambridge University Press.

Halpern, D. F. (1993). Assessing the effectiveness of critical thinking instruction. The Journal of General Education, 42 (4), 238-254.

Harklau, L. (1994). ESL versus mainstream classes: Contrasting L2 learning environments. TESOL Quarterly, 28, 241-272.

Hirose, S. (1992). Critical Thinking in Community Colleges. ASHE-ERIC Higher

Howie, S. H. (1993). Critical thinking: A critical skill for students. Reading TODAY, 24.

Jones, E. A., Hoffman, S., Moore, L. M., Ratcliff, G., Tibbetts, S., \& Click, B. A. L. I. (1995). National Assessment of College Student Learning: Identifying College Graduates' Essential Skills in Writing, Speech and Listening, and Critical 
Thinking. Final Project Report (No. NCES 95-001): National Center on Postsecondary Teaching, Learning, and Assessment, The Pennsylvania State University.

Kabilan, K.M. (2000) Creative and critical thinking in language classroom. Internet TESL Journal, 6(6). http://iteslj.org/Techniques/Kabilan-CriticalThinking.html

Kamali, Z., \& Fahim, M. (2011). The relationship between critical thinking ability of Iranian EFL learners and their resilience level facing unfamiliar vocabulary items in reading. Journal of Language Teaching and Research, 2(1), 104-111

Kaplan, G. 2000. Passion in the classroom. IATEFL literature and cultural studies, 19, 19-21.

Kong, S. L. (2007). Cultivating critical and creative thinking skills. In A.G. Tan (Ed.), Creativity: A handbook for teachers (pp. 303-326). Hackensack, NJ: World Scientific Publishing.

Lun, V. M., Fischer, R., \& Ward, C. (2010). Exploring cultural differences in critical thinking: Is it about my thinking style or the language I speak? Learning and Individual Differences, 20, 604-616. https://doi.org/10.1016/j.lindif.2010.07.001

Mattevi, Y. (2005). Using Drama in the classroom: the educational values of theatre in second language acquisition. (Dissertation). Stony Brook University. UMI number: 3189394

McKay, S. (1987). Literature in the ESL classroom. TESOL Quarterly, 16. 529-236.

Malmir, A., \& Shoorcheh, S. (2012). An investigation of the impact of teaching critical thinking on Iranian EFL learners' speaking skills. Journal of Language Teaching and Research, 3(4), 608-617.

Moon, J. (2008). Critical Thinking. An exploration of theory and practice. London; New York: Routledge.

Murdoch, G. (2002). Exploiting well-known short stories for language skills development. IATEFL LCS SIG Newsletter 23, 9-17

Oatley, K. (2016). Fiction: Simulation of Social Worlds. Trends in Cognitive Sciences, $20(8)$

Oh, K. (2017) Developing Critical Thinking Skills through a Mandatory English Course in Korean Higher Education. English Teaching, 72(4), 53-80. DOI: 10.15858/engtea.72.4.201712.53

Pardede, P. (2015). A Priority Agenda for Mental Revolution in Education: Developing Critical and Creative Thinking through Learning. In Proceeding Mental Revolution in Education for Human Character Building, 104-121

Pardede, P. (2011). Using Short Stories to Teach Language Skills. Journal of English Teaching, (1): 14-27. DOI: http://dx.doi.org/10.33541/jet.v1i1.49

Paul, R., \& Elder, L. (2007). The Miniature Guide to Critical Thinking: Concepts and Tools. Near University of California at Berkeley.

Prodromou, L. (2000). Reason, not the need: Shakespeare in ELT. IATEFL Issues, 156. Retrieved July 2017 from http://www. iatefl.org/archives/Texts/156Prodmorou

Rashid, R.A. and Hashim, R.A. (2008). The relationship between critical thinking and language proficiency of Malaysian undergraduates. EDU-COM 2008 International Conference. Retrieved September 8, 2014, from ro.ecu.edu.au/ceducom/36/

Rear D. (2016). Critical thinking, language and problem-solving: scaffolding thinking skills through debate. In Ruth Breeze \& Carmen Guinda (eds.): Essential 
Competencies for English-Medium University Teaching, pp. 51 - 63. Springer International Publishing.

Rfaner, S. (2006). Enhancing Thinking Skills in the Classroom. Humanity \& Social Sciences Journal, 1(1):28-36

Rosyati, A. R., \& Rosna, A. H. (2008). The relationship between critical thinking and language proficiency of Malaysian undergraduates. Proceedings of the EDUCOM 2008 International Conference. Sustainability in Higher Education: Directions for Change (pp. 373-384). Perth, Western Australia: Edith Cowan University. Retrieved from http://ro.ecu.edu.au/ceducom/36

Rujivanarom, P. (2016, December 14). School system's failure to teach logical thinking linked to low PISA scores. The Nation. Retrieved from http://tinyurl.com/168ugux.

Sadli, S. (2002). Feminism in Indonesia in an international context. In K. Robinson \& S. Bessell (Eds.), Women in Indonesia: Gender, equity, and development (pp. 8092). Singapore: Institute of Southeast Asian Studies.

Savvidou, C. (2004). An Integrated Approach to the Teaching of Literature in the EFL Classroom. The Internet TESL Journal, 10 (12) Retrieved July 2018, from http://iteslj.org/Techniques/Savvidou_Literature.html

Shirkhani, S. \& Fahim, M. (2011). Enhancing critical thinking in foreign language learners. Procedia - Social and Behavioral Sciences, 29, 111 - 115

Siaj, R.N. and Farrah, M.A.A. (2018). Using Novels in the Language Classroom at Hebron University. Journal of Creative Practices in Language Learning and Teaching (CPLT), 6(2), 44-59

Spalding, W.B. (1961). Teaching Language and Literature. New York: Harcourt, Brace \& World, Inc.

Stapleton, P. (2011). A survey of attitudes towards critical thinking among Hong Kong secondary school teachers: Implications for policy change. Thinking Skills and Creativity Journal, 6(1), 14-23.

Stapleton, P. (2002). Critical thinking in Japanese L2 writing: Rethinking tired constructs. ELT Journal, 56, 250-257.

Tung, C. \& Chang, S. (2009). Developing Critical Thinking through Literature Reading. Feng Chia Journal of Humanities and Social Sciences, No. 19, 287-317

Tang, L. (2016). Exploration on the cultivation of critical thinking in college intensive reading course. English Language Teaching, 9(3), 18-23. http://dx.doi.org/10.5539/elt.v9n3p18

Taylor, R. (1981). Understanding the Elements of Literature. London and Basingstoke: The Macmillan Press Ltd.

Wessels, C. (1987). Drama. Oxford: Oxford University Press.

Young, A. (1996). Introducing critical thinking at the college level with children's stories. College Teaching, 44(3), 90 